Volume 2 Nomor 1 Edisi Juni 2013

ISSN 2354-7200
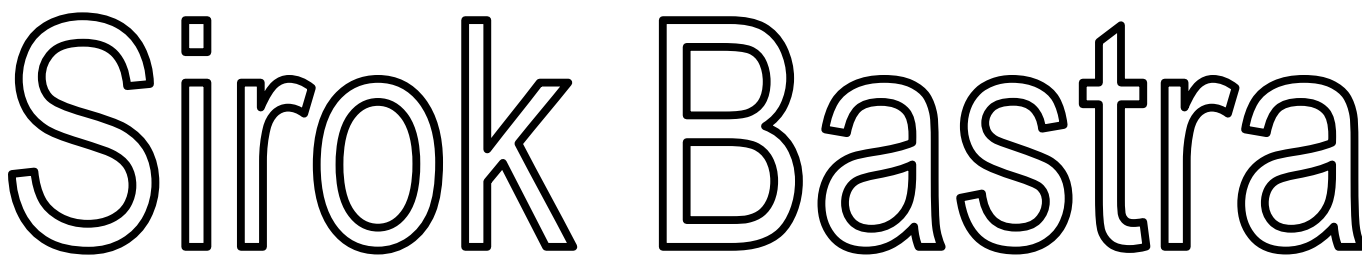

JURNAL ILMIAH KEBAHASAAN DAN KESASTRAAN

\begin{tabular}{|c|c|l|c|c|c|}
\hline $\begin{array}{c}\text { Sirok Bastra } \\
\text { Jurnal Kebahasaan dan } \\
\text { Kesastraan }\end{array}$ & Volume 2 & Nomor 1 & $\begin{array}{c}\text { Hlm. } \\
1-120\end{array}$ & $\begin{array}{c}\text { Pangkalpinang, } \\
\text { Juni 2013 }\end{array}$ & $\begin{array}{c}\text { ISSN } \\
2354-7200\end{array}$ \\
\hline
\end{tabular}

KANTOR BAHASA PROUINSI BANGKA BELITUNG 


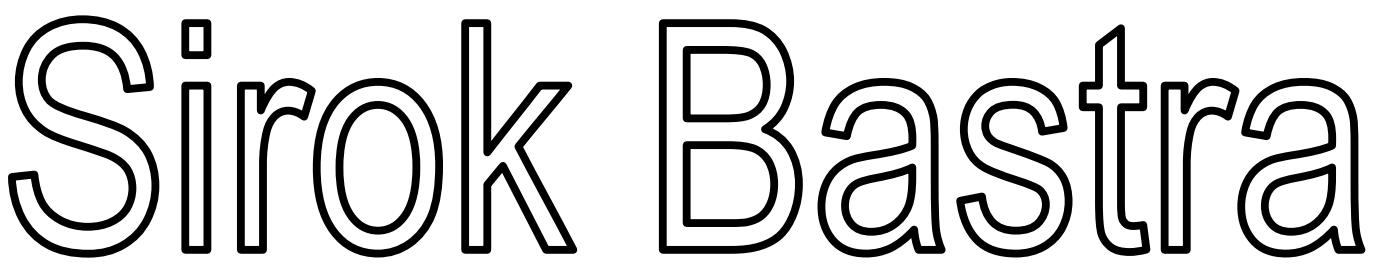

\section{JURNAL ILMIAH KEBAHASAAN DAN KESASTRAAN}

Jurnal ini merupakan wadah informasi mengenai kebahasan, kesastraan, dan pengajarannya yang memuat hasil penelitian, studi kepustakaan, dan tulisan ilmiah bidang kebahasan dan kesastraan serta pengajarannya. Sirok Bastra terbit dua kali setahun, yakni Juni dan Desember, serta terbit sejak Juni 2013.

\section{Penanggung Jawab}

Kepala Kantor Bahasa Provinsi Bangka Belitung Drs. Umar Solikhan, M.Hum.

\section{Mitra Bestari}

Prof. Dr. Agus Nuryatin, M.Hum. (Bidang Sastra dan Pengajarannya)

Prof. Amrin Saragih, Ph.D., M.A. (Bidang Bahasa dan Pengajarannya)

Dr. Felicia Nuradi Utorodewo, M.Hum. (Bidang Bahasa dan Pengajarannya)

Dr. Pujiharto, M.Hum. (Bidang Sastra dan Pengajarannya)

\section{Pemimpin Redaksi}

Rahmat Muhidin, S.S.

\section{Penyunting}

Prima Hariyanto, S.Hum.

\section{Perancang Sampul}

Feri Pristiawan, S.S.

\section{Kesekretariatan}

Khaliffitriansyah, S.Pd.

Dea Letriana Cesaria, S.Hum.

Lia Aprilina, S.Pd.

Andrian Priyatno, A.Md.

Elzam

\section{Alamat Redaksi dan Penerbit}

Kantor Bahasa Provinsi Bangka Belitung

Ruko Permata 7, Jalan Solihin G.P. Km 4, Kota Pangkalpinang, Prov. Kepulauan Bangka Belitung

Telp./Faks.: 0717-438455, Pos-el: sirokbastra@gmail.com

Pemuatan suatu tulisan dalam jurnal ini tidak berarti redaksi menyetujui isi tulisan tersebut. Isi tulisan menjadi tanggung jawab penulis. Tulisan telah ditinjau dan diulas oleh mitra bestari. Setiap karangan dalam jurnal ini dapat diperbanyak setelah mendapat izin tertulis dari penulis, redaksi, dan penerbit. 


\section{PENGANTAR}

Puji syukur ke hadirat Pemilik dan Pencipta semesta ini yang memiliki kuasa atas diri-Nya sendiri. Dialah Tuhan Yang Maha Esa yang telah memberikan rahmat dan hidayah-Nya sehingga Volume 2 Nomor 1 Jurnal Sirok Bastra Tahun 2014 dapat terbit tepat pada waktunya.

Pada edisi ini, dimuat sepuluh tulisan, yakni enam tulisan kesastraan dan empat tulisan kebahasaan. Dalam kajiannya, Anita Rima Dewi melihat kedudukan perempuan Jawa dalam keluarga — tergambar dalam novel Hati Sinden karya Dwi Rahyuningsih — dilihat dari perspektif gender. Berdasarkan penelitian, ditemukan bahwa diskriminasi gender seperti marginalisasi, stereotipe, dan subordinasi melahirkan berbagai kekerasan, yakni ekonomi, fisik, psikis, dan seksual.

Dalam kajiannya, Sarman membahas mitos buluh perindu dalam cerita rakyat Bangka. Mitos Bukit Tambun Tulang memuat struktur geografis yang menunjukkan adanya pola perjalanan hidup tokoh dalam mempertahankan hidup; struktur tekno-ekonomi yang menunjukkan adanya sistem mata pencaharian orang Bangka, antara lain berburu dan berkebun; struktur sosiologis yang menunjukan adanya hubungan sosial antara sesama manusia; dan struktur kosmologis yang menunjukkan adanya keterkaitan antara dunia nyata dan dunia gaib.

Dalam penelitiannya, Iis Afriatiningsih membahas sosok perempuan dalam karya sastra Indonesia yang diwakili oleh Nyai Ontosoroh, Pariyem, Clara yang menghadapi banyak tantangan dalam hidupnya. Hasil analisis menunjukkan bahwa sosok perempuan memiliki sikap, seperti memperjuangkan hidupnya (tergambar dalam tokoh Nyai Ontosoroh), pasrah dengan nasibnya (tergambar dalam tokoh Pariyem), dan nasibnya ada di tangan rakyat kecil (tergambar dalam tokoh Clara). Perjuangan perempuan tersebut berkaitan dengan kritik formalisme, strukturalisme, posstrukturalisme, dan posmoderenisme.

Dalam kajiannya, Asep Supriadi mengaplikasikan teori takmilah yang digagas oleh seorang pakar sastra Melayu bernama Shafie Abu Bakar pada puisi "Idul Fitri" karya Sutardji Calzoum Bachri. Hasil kajian menunjukkan bahwa puisi tersebut menggambarkan nilai-nilai keislaman dengan dimensi sufistik. Puisi itu menggambarkan perenungan eksistensi diri pada Tuhan.

Dalam kajiannya, Ch. Haris Maulana membahas tokoh dan penokohan serta nilai moral dan kekhasan yang ada dalam serial Harry Potter, khususnya seri pertama, Harry Potter dan Batu Bertuah. Nilai moral dan kekhasan yang tersirat dalam serial ini adalah sihir dapat dipelajari dan bukan faktor keturunan, kesetiakawanan, kedisipilinan, kepedulian, dan keingintahuan.

Dalam penelitiannya, Dwi Oktarina menggali aspek hibriditas dan ambivalensi yang terjadi pada tokoh Mata Hari dalam novel Namaku Mata Hari karya Remy Silado. Mata Hari, seorang agen spionase keturunan Belanda-Jawa bekerja pada banyak negara pada saat perang dunia berkecamuk. Selain itu, permainan politik tubuh Mata Hari juga menjadi sebuah hal yang menarik untuk diteliti lebih jauh. Berdasarkan penelitian, didapatkan hasil bahwa ruang-ruang pertemuan antara dua kebudayaan sama sekali tidak bisa dielakkan. Mata Hari sebagai Indo berdarah campuran Belanda-Indonesia tidak dapat melepaskan dirinya dari dua kebudayaan yang melingkupinya, Belanda maupun Indonesia.

Dalam kajiannya, Maria Christa Istiana Kamagi membahas struktur kalimat dan keterbacaan pada buku teks pelajaran bahasa Indonesia. Berdasarkan penelitian, ditemukan kalimat tunggal perluasan subjek, predikat, objek, dan pelengkap, kalimat tunggal perluasan keterangan, kalimat majemuk setara, kalimat majemuk bertingkat, kalimat majemuk bersusun, dan kalimat taklengkap. Selain menjelaskan struktur kalimat yang ada, penelitian ini juga mencoba menganalisis keterbacaan dilihat dari jumlah kata yang digunakan dalam kalimat tersebut. Hasil yang didapat adalah terdapat beberapa kalimat yang masih masuk kategori kalimat sulit dan sangat sulit dipahami.

Dalam kajiannya, Achril Zalmansyah membahas hasil Uji Kemahiran Berbahasa Indonesia (UKBI) guru dan siswa SMP di Kabupaten Lampung Utara. Data yang diperoleh menunjukkan bahwa sebagian besar peserta memperoleh nilai antara 300-400 yang berarti cukup baik. Dengan demikian, dapat dikatakan bahwa UKBI 
merupakan alat uji yang dapat digunakan untuk mengukur penguasaan bahasa Indonesia seorang guru serta penggunaan bahasa Indonesia yang baik dan benar oleh siswa.

Dalam kajiannya, Prima Hariyanto membahas kata berinfiks -er- dalam bahasa Indonesia. Korpus data penelitian ini adalah Kamus Besar Bahasa Indonesia Edisi Ketiga. Berdasarkan penelitian yang dilakukan, ditemukan 62 kata berinfiks -er- yang terdiri dari 14 jenis kelompok makna. Selain memaparkan kata berinfiks yang ada, penelitian ini juga mencoba memaparkan metode pendefinisian lema kata berinfiks yang -er-bermakna 'sama dengan bentuk dasarnya' dalam Kamus Besar Bahasa Indonesia.

Dalam penelitiannya, Hotnida Novita Sary mengkaji perbedaan bentuk verba yang terdapat dalam bahasa Melayu Tinggi dan bahasa Melayu Rendah yang terdapat dalam Injil Matius terjemahan Klinkert. Peneliti mengunduh data dari laman sabda.org. Kedua versi Injil Matius ini kemudian dibandingkan dan dicatat satu ayat dengan ayat yang sama. Hasil pencatatan inilah yang dianalisis. Hasil yang didapatkan dari penelitian ini adalah ragam bahasa Melayu Tinggi cenderung menggunakan bentuk berimbuhan, sedangkan bahasa Melayu Rendah cenderung menggunakan bentuk dasar.

Kami mengucapkan terima kasih kepada para penulis yang telah bersedia menerbitkan karya mereka pada edisi ini. Para penulis merupakan peneliti, pakar, dosen, siswa, dan mahasiswa dari berbagai sekolah, perguruan tinggi, dan instansi. Terima kasih juga kami sampaikan kepada para mitra bestari kami yang telah memberi ulasan terhadap tulisan-tulisan yang masuk ke redaksi.

Demi memenuhi keberagaman isi dan penulis, Sirok Bastra membuka kesempatan bagi para peneliti dan penulis menyampaikan hasil penelitian dan pemikiran mutakhir dalam bidang kebahasaan, kesastraan, dan pengajarannya.

Pangkalpinang, Juni 2014

Tim Redaksi 


\section{UCAPAN TERIMA KASIH UNTUK MITRA BESTARI}

Redaksi Sirok Bastra mengucapkan terima kasih kepada para mitra bestari yang telah meninjau, menimbang, dan mengulas makalah-makalah yang diterbitkan dalam Sirok Bastra Volume 2 Nomor 1, edisi Juni 2014, yakni

Prof. Dr. Agus Nuryatin, M.Hum.

Bidang Sastra dan Pengajarannya

Universitas Negeri Semarang

Semarang, Jawa Tengah

Prof. Amrin Saragih, Ph.D., M.A.

Bidang Bahasa dan Pengajarannya

Universitas Negeri Medan

Medan, Sumatra Utara

Dr. Felicia Nuradi Utorodewo, M.Hum.

Bidang Bahasa dan Pengajarannya

Universitas Indonesia

Depok, Jawa Barat

\section{Dr. Pujiharto, M.Hum.}

Bidang Sastra dan Pengajarannya

Universitas Gadjah Mada

Yogyakarta, Daerah Istimewa Yogyakarta 


\section{DAFTAR ISI}

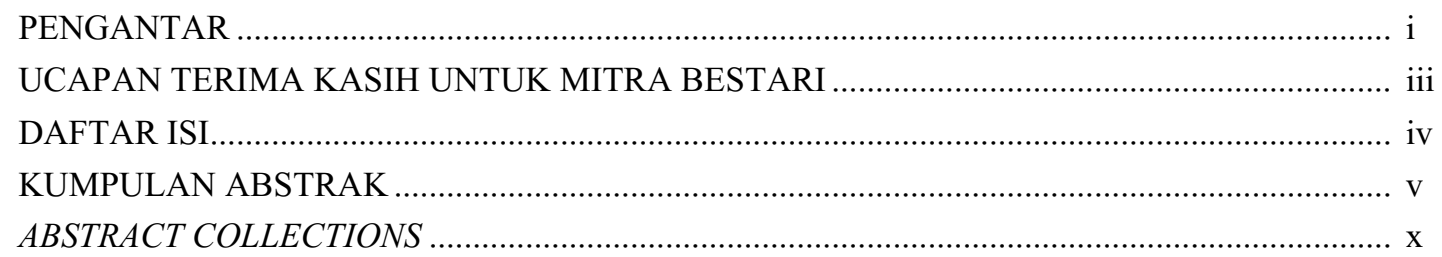

KEDUDUKAN PEREMPUAN JAWA DALAM NOVEL HATI SINDEN KARYA DWI RAHYUNINGSIH DILIHAT DARI PERSPEKTIF GENDER

(The Position of Javanese Women Based on Gender Perspective in Hati Sinden, a Novel by Dwi Rahyuningsih)

Anita Rima Dewi $1-15$

MITOS DALAM CERITA “BUKIT TAMBUN TULANG”

(Myth in "Bukit Tambun Tulang" Story)

Sarman. $17-24$

SOSOK PEREMPUAN DARI ZAMAN KE ZAMAN DALAM KARYA SASTRA INDONESIA: STUDI KASUS TOKOH NYAI ONTOSOROH, PARIYEM, DAN CLARA (Figure of Women from Time to Time in Indonesian Literary Works: A Case Study of Nyai Ontosoroh, Pariyem, and Clara)

Iis Afriatiningsih $25-33$

MEMAHAMI PUISI "IDUL FITRI" DENGAN TEORI TAKMILAH

(Understanding the Poetry "Idul Fitri” by Using Theory of Takmilah)

Asep Supriadi $35-44$

NILAI DAN KEKHASAN SERIAL HARRY POTTER (KAJIAN HARRY POTTER 1: HARRY POTTER DAN BATU BERTUAH)

(Value and Uniqueness of Harry Potter Series [A Study of Harry Potter 1: Harry Potter and The Sorcerers Stone])

Ch. Haris Maulana $45-52$

HIBRIDITAS DAN POLITIK TUBUH DALAM NOVEL NAMAKU MATA HARI KARYA REMY SILADO: SEBUAH TINJAUAN POSKOLONIAL

(Hybridity and Body Politic in Namaku Mata Hari, A Novel Written by Remy Silado: A Postcolonial Study)

Dwi Oktarina $53-61$

STRUKTUR DAN KETERBACAAN KALIMAT PADA BUKU TEKS PELAJARAN BAHASA INDONESIA

(Sentence Structure and Readability in Indonesian Textbook)

Maria Christa Istiana Kamagi. $63-78$ 
UJI KEMAHIRAN BERBAHASA INDONESIA (UKBI) BAGI GURU DAN SISWA SEKOLAH MENENGAH PERTAMA SE-LAMPUNG UTARA

(Indonesian Proficiency Test [UKBI] for Teacher and Junior High School Students All Lampung Utara)

Achril Zalmansyah

KATA BERINFIKS -ER- DALAM BAHASA INDONESIA

(-er- Infixes Words in Indonesian)

Prima Hariyanto

$89-103$

PERBEDAAN BENTUK VERBA PADA BAHASA MELAYU TINGGI DAN BAHASA

MELAYU RENDAH: STUDI KASUS INJIL MATIUS TERJEMAHAN KLINKERT

(Verb Form of Differences in Language Malay Malay Language High and Low: Case Study of The Gospel of Matthew Klinkert Translations)

Hotnida Novita Sary .... $105-120$ 


\title{
KATA BERINFIKS -ER- DALAM BAHASA INDONESIA
}

-er- Infixes Words in Indonesian

Prima Hariyanto

Kantor Bahasa Provinsi Bangka Belitung

Ruko Permata 7, Jln. Solihin G.P. Km 4, Pangkalpinang

Pos-el: patriyawhura@gmail.com

(diterima 11 Maret 2014, disetujui 8 April 2014, revisi terakhir 10 Juni 2014)

\begin{abstract}
Abstrak
Dalam makalah ini, dibahas kata berinfiks -er- dalam bahasa Indonesia. Penelitian ini menggunakan metode deskriptif. Teknik pengumpulan data yang digunakan adalah analisis kepustakaan. Korpus data penelitian ini adalah Kamus Besar Bahasa Indonesia Edisi Ketiga. Berdasarkan penelitian yang dilakukan, ditemukan 62 kata berinfiks -er- yang terdiri dari 14 jenis kelompok makna. Selain memaparkan kata berinfiks yang ada, penelitian ini juga mencoba memaparkan metode pendefinisian lema kata berinfiks yang -er- bermakna 'sama dengan bentuk dasarnya’ dalam Kamus Besar Bahasa Indonesia.
\end{abstract}

Kata kunci: infiks, -er-, makna, lema

\begin{abstract}
Abstrack
In this paper, -er- infixed words in Indonesian is discussed. This research uses descriptive method. Technique for collecting data is bibliographical analysis. The data corpus of this research is Kamus Besar Bahasa Indonesia (Third Edition). From the research, 62 -er- infixes words and 14 meaning of -er-infixes words are found. Besides showing all of the infixes, this research also explains the method to define entries with -er-infix which have 'the same meaning with their bases' in Kamus Besar Bahasa Indonesia.
\end{abstract}

Keywords: infix, -er-, meaning, entries

\section{PENDAHULUAN}

\subsection{Latar Belakang}

Kata-kata berinfiks dibentuk dari morfem dasar yang disisipi infiks. Infiksasi merupakan salah satu proses morfologis dalam pembentukan kata. Dalam proses pembentukannya, infiks diletakkan di antara konsonan dan vokal pada suku kata pertama. Sebagai contoh, imbuhan -er-jika disisipkan pada kata bewok, akan disisipkan pada suku kata pertama (be) sehingga menjadi berewok. Dalam perkembangannya, infiks ini semakin lama semakin tidak produktif lagi. Jarang sekali-bahkan tidak pernah-muncul kata-kata berinfiks baru dari infiks yang ada. Kata-kata berinfiks yang ada saat ini merupakan kata-kata yang sudah ada sejak dahulu; bukan kata bentukan yang baru.

Akan tetapi, jika kita melihatnya dari sudut pandang yang berbeda, ada kemungkinan lain mengenai kata-kata berinfiks. Infiks dapat diteliti menggunakan metanalisis, yaitu adanya kemungkinan derivasi balik dari kata-kata berinfiks. Kata-kata berinfiks yang sudah ada sejak dahulu mungkin saja memang merupakan kata-kata atau morfem dasar yang bukan merupakan kata bentukan dari proses infiksasi. Kemungkinan tersebut disebabkan oleh adanya proses morfologis dalam bahasa Indonesia berupa abreviasi atau pemendekan. Hal ini dapat terjadi pada kata-kata yang kini disebut sebagai kata berinfiks. Kata-kata yang dulu merupakan bentuk dasar dan mengalami abreviasi bentuk dasarnya masih tetap digunakan dalam perkembangannya. Oleh karena itu, bentuk dasar dari proses abreviasi tersebut dianggap sebagai kata berinfiks pada saat ini. Asumsi seperti ini merupakan kebalikan dari teori yang telah ada sebelumnya yang mengatakan bahwa kata-kata berinfiks merupakan hasil dari afiksasi.

\subsection{Masalah}

Bahasa adalah sebuah sistem. Hal ini berarti bahwa bahasa bukan merupakan sejumlah unsur yang 
terkumpul secara tidak beraturan. Seperti halnya sistem-sistem yang lain, unsur-unsur dalam bahasa diatur seperti pola-pola yang berulang sehingga jika salah satu bagian saja terlihat, dapat diramalkan keseluruhannya (Kridalaksana, 1990: 2). Infiks sebagai salah satu unsur dalam proses pembentukan kata dalam bahasa Indonesia juga memiliki keteraturan pola. Akan tetapi, belum ada penelitian lebih mendalam berkaitan dengan infiks dalam bahasa Indonesia. Berdasarkan hal tersebut, penulis menemukan adanya permasalahan yang akan dibahas dalam penelitian ini, yaitu kata-kata apa saja dalam Kamus Besar Bahasa Indonesia Edisi Ketiga yang merupakan kata berinfiks - er- serta bagaimana makna dan metode pendefinisian kata berinfiks -er- yang bermakna 'sama dengan bentuk dasarnya' dalam Kamus Besar Bahasa Indonesia Edisi Ketiga.

\subsection{Tujuan}

Berdasarkan masalah tersebut, tujuan penelitian ini adalah sebagai berikut.

1. Memaparkan kata-kata mana saja dalam Kamus Besar Bahasa Indonesia Edisi Ketiga yang merupakan kata berinfiks dalam bahasa Indonesia.

2. Menjelaskan makna infiks -er- dalam bahasa Indonesia berdasarkan data.

3. Menjelaskan metode pendefinisian kata berinfiks er- yang bermakna 'sama dengan bentuk dasarnya' dalam Kamus Besar Bahasa Indonesia Edisi Ketiga

\subsection{Metode Penelitian}

Dalam penelitian ini, penulis menggunakan metode deskriptif, yaitu metode berdasarkan fakta yang ada atau fenomena yang secara empiris hidup pada pengguna-penggunanya. Dengan demikian, hasil yang diperoleh merupakan pemerian bahasa apa adanya secara terperinci dan mendalam (Sudaryanto, 1988: 62). Teknik pengumpulan data yang digunakan dalam penelitian ini adalah analisis kepustakaan. Teknik kepustakaan digunakan untuk menganalisis data yang ditemukan agar dapat tercapai tujuan penelitian ini, yaitu kata mana saja yang merupakan kata berinfiks serta bagaimana makna dan metode pendefinisian kata berinfiks -er- yang bermakna 'sama dengan bentuk dasarnya' dalam Kamus Besar Bahasa Indonesia Edisi Ketiga.

Langkah-langkah penelitian yang dilakukan oleh penulis meliputi pengumpulan data, pemeriksaan data, dan penganalisisan data. Langkah pertama adalah pengumpulan data. Data dikumpulkan dengan mencari kata-kata yang dicurigai mengandung infiks dalam Kamus Besar Bahasa Indonesia Edisi Ketiga cetakan tahun 2005.

Penulis mendaftar seluruh kata dalam $K B B I$ yang mengandung bentuk -er-. Pada tahap pertama ini, penulis belum memperhatikan letak bentuk infiks tersebut, apakah di suku kata awal, tengah, atau akhir sehingga ditemukan 3.858 kata. Dari daftar kata yang telah ditemukan tersebut, penulis mencari kata-kata yang dicurigai sebagai kata berinfiks, yaitu dengan menggunakan ciri bahwa infiks diletakkan di antara konsonan dan vokal pada suku kata pertama. Sebagai contoh pada tahap pertama ditemukan kata apoteker, deregulasi, dan berewok. Sesuai ciri di atas, hanya deregulasi dan berewok yang dimasukkan ke tahap kedua, sedangkan apoteker dieliminasi karena tidak sesuai ciri. Pada tahap ini ditemukan 1.058 kata.

Data tersebut disaring lagi dengan menghilangkan bentuk -er- untuk mencari bentuk dasarnya. Sebagai contoh, pada tahap sebelumnya ditemukan kata deregulasi dan berewok. Kedua kata tersebut dihilangkan bentuk -er- sehingga menjadi degulasi dan bewok. Setelah dicek di $K B B I$, hanya ditemukan kata bewok. Bentuk degulasi tidak dikenal dalam bahasa Indonesia sehingga degulasi dieliminasi pada tahap ini. Pada tahap ini ditemukan 325 pasang kata.

Dari data yang dihasilkan pada tahap ketiga tersebut, penulis meneliti kembali setiap pasangan kata tersebut, apakah memiliki keterkaitan makna atau tidak. Jika ditemukan keterkaitan makna antara kata yang dianggap berinfiks dan kata yang dianggap sebagai bentuk dasarnya, pasangan tersebut dimasukkan ke dalam kelompok selanjutnya, yaitu kelompok kata berinfiks. Pasangan kata inilah yang dianalisis lebih lanjut untuk ditentukan apakah merupakan pasangan kata berinfiks dan bentuk dasarnya atau bukan.

Metode morfologis yang digunakan untuk meneliti kata-kata yang ditemukan tersebut adalah metode analisis struktural dengan model penataan. 
Metode penataan atau tata nama meneliti data berdasarkan unsur-unsur gramatikal yang ada. Sebagai contoh, kata gigi dan gerigi.

$\begin{array}{ll}\text { gigi } & \text { gigi } \\ \text { gerigi } & \text { banyak gigi }\end{array}$

Dari contoh di atas dapat dilihat bahwa perubahan bentuk gigi menjadi gerigi mengalami perubahan makna. Infiks -er- pada contoh tersebut mewakili konsep makna 'banyak'.

Sebagaimana disebutkan oleh Hocket (1959) dan Robins (1960) (dalam Kridalaksana, 2007: 24-25), dalam linguistik terdapat beberapa model analisis, yaitu model proses, model penataan, dan model paradigma. Untuk menjelaskan model penataan dan model paradigma, digunakan kata pesuruh sebagai contoh; sedangkan untuk menjelaskan model proses, digunakan kata ajar sebagai contoh.

Model penataan atau model tata nama (itemand-arrangement model) menyajikan unsur-unsur gramatikal-dalam hal ini morfem-dan memperlihatkan bagaimana hubungan di antara unsur-unsur tersebut. Kata pesuruh terbentuk dari morfem afiks pe-dan morfem suruh.

Dalam model paradigma (word-and-paradigm model), yang diperlakukan sebagai satuan dasar adalah kata, dan unsur-unsur kata, yakni morfem, diperlihatkan secara tersirat. Kata pesuruh disajikan bersama dengan kata lain yang mengandung namanama yang mirip: pesuruh, penyuruh, menyuruh, dan suruhan.

Dalam model proses (item-and-process model) diakui dua komponen, yaitu dasar dan proses. Sebagai contoh kata ajar yang dibentuk menjadi kata polimorfemis dengan kelas verba. Kata ajar dapat dibentuk menjadi belajar dan mengajar. Dari bentuk belajar dibentuk lagi menjadi 'pelaku' pelajar, sedangkan mengajar menjadi pengajar. Bentuk pelajar dapat dibentuk lagi menjadi nomina pelajaran, sedangkan pengajar menjadi pengajaran.

Langkah kedua adalah pemeriksaan data. Data yang telah diperoleh diperiksa apakah benar-benar merupakan kata berinfiks atau bukan. Langkah terakhir adalah penganalisisan data. Dari data yang telah tersusun tadi kemudian dianalisis sesuai dengan permasalahan dan tujuan yang ingin dicapai dalam penelitian ini.
Korpus data yang digunakan dalam penelitian ini adalah Kamus Besar Bahasa Indonesia Edisi Ketiga. Untuk mempermudah pengambilan data, penulis juga menggunakan KBBI Daring (Error! Hyperlink reference not valid.) yang merupakan edisi online dari Kamus Besar Bahasa Indonesia Edisi Ketiga. Alasan pemilihan edisi ketiga sebagai data adalah penilaian dari beberapa pihak yang menyatakan bahwa edisi terbaru $K B B I$ (edisi keempat) memiliki lebih banyak kekurangan daripada edisi ketiganya. Hal ini dikemukakan oleh beberapa pembicara dalam Bedah Kamus Besar Bahasa Indonesia Pusat Bahasa Edisi IV pada hari Selasa, 24 Februari 2009, di Bentara Budaya Jakarta.

\section{KERANGKA TEORI}

Penelitian mengenai infiks -er- dalam bahasa Indonesia telah banyak dilakukan oleh para ahli linguistik bahasa Indonesia, baik ahli dari dalam maupun luar negeri. Akan tetapi, pembahasan mengenai infiks oleh para ahli tersebut hanya secara garis besar, belum secara mendalam. Pembahasan mengenai infiks tersebut selalu bergabung dan menjadi bagian dari penelitian mengenai proses morfologis maupun dalam tata bahasa yang dibuat oleh para ahli linguistik. Penelitian itu pun tidak terbatas pada bahasa Indonesia saja, tetapi juga bahasa Melayu sebagai akar bahasa Indonesia.

\subsection{Pengertian Infiks}

Menurut Gorys Keraf (1984), infiks adalah morfem nondasar yang secara struktural dilekatkan di tengah sebuah kata, yaitu antara konsonan yang mengawali sebuah kata dan vokal berikutnya.

\subsection{Bentuk Infiks}

Menurut Harimurti Kridalaksana (1992), dalam bahasa Indonesia terdapat empat macam infiks, yaitu -em-, -el-, -er-, dan -in-. Infiks -em- dan -indikategorikan sebagai afiks pembentuk adjektiva, sedangkan infiks -el- dan -er- dikategorikan sebagai afiks pembentuk nomina. Keempat infiks ini tidak mengalami perubahan morfofonemik (tidak beralomorf). 


\subsection{Makna Infiks}

Menurut Harimurti Kridalaksana (1992), infiks em- bermakna (1) 'menyatakan banyak, bermacammacam, atau kumpulan'; (2) 'menyatakan intensitas, frekuensi'; dan (3) 'mempunyai sifat atau memiliki hal yang disebut dalam kata dasar'.

Infiks -el- bermakna (1) 'menyatakan yang melakukan; alat (instrumentalis) atau memiliki hal yang disebut dalam kata dasar'; (2) 'menyatakan intensitas'; (3) 'menyatakan banyak atau bermacammacam'; (4) 'berarti benda yang...'; dan (5) 'berarti terjadi, berlaku, atau melakukan yang pelaku atau tindakannya banyak'.
Infiks -er- bermakna (1) 'menyatakan banyak atau bermacam-macam'; (2) 'menyatakan alat (instrumentalis)'; (3) 'mempunyai sifat atau memiliki hal yang disebut dalam kata dasar'; (4) 'menyatakan berulang, terus-menerus, intensitas'.

Infiks -in- bermakna (1) 'berlangsung beberapa lama (kontinu)'; (2) 'mempunyai sifat atau memiliki hal yang disebut dalam kata dasar'.

\section{HASIL DAN PEMBAHASAN}

\subsection{Kata Berinfiks -er-}

Berdasarkan analisis yang dilakukan terhadap pasangan dugaan kata berinfiks dan dugaan bentuk dasarnya (hasil dari tahap ketiga), ditemukan 62 kata berinfiks $-e r$.

Tabel 1: Kata Berinfiks -er-

\begin{tabular}{|c|c|c|c|}
\hline No. & Kata Berinfiks & No. & Bentuk Dasar \\
\hline $1 \mathrm{a}$ & be-ra·ngus & $1 b$ & ba·ngus \\
\hline $2 \mathrm{a}$ & be·reng·gil & $2 b$ & beng.gil \\
\hline $3 \mathrm{a}$ & be·re·wok & $3 b$ & be·wok \\
\hline $4 \mathrm{a}$ & ${ }^{1}$ be $\cdot$ rum $\cdot$ bung & $4 \mathrm{~b}$ & bum·bung \\
\hline $5 \mathrm{a}$ & ce·ra·but & $5 b$ & ca·but \\
\hline $6 \mathrm{a}$ & ce·ra·cak, ber·ce·ra·cak & $6 \mathrm{~b}$ & ${ }^{1} \mathrm{ca} \cdot \mathrm{cak}$ \\
\hline $7 \mathrm{a}$ & ce·ra·cau, men·ce·ra·cau & $7 \mathrm{~b}$ & $\mathrm{ca} \cdot \mathrm{cau}$ \\
\hline $8 \mathrm{a}$ & ce·ran·cang, ber·ce·ran·cang·an & $8 \mathrm{~b}$ & ${ }^{1}$ can $\cdot$ cang \\
\hline $9 \mathrm{a}$ & ce·rang·gah & $9 b$ & ${ }^{1}$ cang·gah \\
\hline $10 \mathrm{a}$ & ce·ra·tuk, ber·ce·ra·tuk & $10 \mathrm{~b}$ & ${ }^{4} \mathrm{ca} \cdot \mathrm{tuk}$, ter $\cdot \mathrm{ca} \cdot \mathrm{tuk}$ \\
\hline $11 \mathrm{a}$ & ge·ra·gap, meng·ge $\cdot$ ra·gap & $11 \mathrm{~b}$ & ${ }^{1}$ ga·gap \\
\hline $12 \mathrm{a}$ & ge'ra·pai $v$, meng'ge'ra·pai & $12 \mathrm{~b}$ & ga'pai $v$, ber'ga'pai-an \\
\hline $13 \mathrm{a}$ & ge're'nyot & $13 b$ & ge·nyot \\
\hline $14 \mathrm{a}$ & ge·ri·gi & $14 \mathrm{~b}$ & gi·gi \\
\hline $15 \mathrm{a}$ & ge'ri·gis & $15 b$ & ${ }^{2}$ gi.gis \\
\hline $16 \mathrm{a}$ & ge·rin·jal & $16 \mathrm{~b}$ & gin.jal \\
\hline $17 \mathrm{a}$ & ge·ro·hong & $17 \mathrm{~b}$ & go hong \\
\hline $18 \mathrm{a}$ & ge·rong·gong & $18 b$ & gong·gong \\
\hline $19 \mathrm{a}$ & ge·ru·nyam & $19 b$ & gu·nyam $v$, meng·gu·nyam \\
\hline $20 \mathrm{a}$ & je·ra $\cdot m a h$, ber·je·ra $\cdot m a h$ & $20 \mathrm{~b}$ & $\mathrm{ja} \cdot \mathrm{mah} v, \mathrm{men} \cdot \mathrm{ja} \cdot \mathrm{mah}$ \\
\hline $21 \mathrm{a}$ & je $\cdot \mathrm{rem} \cdot \mathrm{ba}, \mathrm{men} \cdot \mathrm{je} \cdot \mathrm{rem} \cdot \mathrm{ba}$ & $21 b$ & ${ }^{2}$ jem $\cdot$ ba, men $\cdot$ jem $\cdot$ ba \\
\hline $22 \mathrm{a}$ & je·ro·jol, men·je·ro·jol & $22 b$ & ${ }^{2}$ jo·jol, men·jo·jol \\
\hline $23 \mathrm{a}$ & je·rong $\cdot$ kok $v$, men·je·rong $\cdot$ kok & $23 b$ & jong.kok \\
\hline $24 \mathrm{a}$ & je·ru·bung & $24 b$ & ju·bung \\
\hline $25 \mathrm{a}$ & je.rum·bai & $25 b$ & jumbbai \\
\hline $26 a$ & ke·ra·kap & $26 b$ & ${ }^{4} \mathrm{ka} \cdot \mathrm{kap}$ \\
\hline $27 \mathrm{a}$ & ke·rang $\cdot$ kang & $27 b$ & kang $\cdot$ kang \\
\hline $28 \mathrm{a}$ & ke·re·ceng & $28 \mathrm{~b}$ & ke·ceng \\
\hline $29 \mathrm{a}$ & ke·rem·pung & $29 b$ & ${ }^{2}$ kem·pung \\
\hline $30 \mathrm{a}$ & ke·re $\cdot$ mun'ting & $30 \mathrm{~b}$ & ke.mun.ting \\
\hline $31 \mathrm{a}$ & ke·re·nyit & $31 b$ & ke'nyit, me·nge'nyit \\
\hline $32 \mathrm{a}$ & ke·re·pak & $32 b$ & ${ }^{3} \mathrm{ke} \cdot \mathrm{pak}$, ter·ke·pak \\
\hline $33 a$ & ke're'pot & $33 b$ & ${ }^{1}$ ke·pot \\
\hline
\end{tabular}


Prima Hariyanto: Kata Berinfiks -er- dalam Bahasa Indonesia

\begin{tabular}{|c|c|c|c|}
\hline $34 \mathrm{a}$ & ke·ri·cau, ber ke·ri·cau & $34 \mathrm{~b}$ & ${ }^{1} \mathrm{ki} \cdot \mathrm{cau}$ \\
\hline $35 \mathrm{a}$ & ke·ri-sut & $35 \mathrm{~b}$ & ${ }^{1} \mathrm{ki} \cdot$ sut \\
\hline $36 \mathrm{a}$ & ke'ro'cok & $36 \mathrm{~b}$ & ko cok \\
\hline $37 \mathrm{a}$ & ke·ro·pong & $37 \mathrm{~b}$ & ko.pong \\
\hline $38 \mathrm{a}$ & ke'ru·dung & $38 \mathrm{~b}$ & ${ }^{2} \mathrm{ku} \cdot \mathrm{dung}$ \\
\hline $39 a$ & ke·ru'kut $v$, me'nge·ru'kut & $39 \mathrm{~b}$ & $\mathrm{ku} \cdot \mathrm{kut}$ \\
\hline $40 \mathrm{a}$ & pe'ran·cit & $40 \mathrm{~b}$ & pan'cit $v$, me'man'cit \\
\hline $41 \mathrm{a}$ & pe'ra·ngah, me·me'ra·ngah'kan & $41 b$ & pa.ngah, ter.pa'ngah \\
\hline $42 \mathrm{a}$ & pe·ra·suk·an & $42 \mathrm{~b}$ & pa·suk, ber·pa·suk-pa·suk \\
\hline $43 a$ & re'ra·mu'an & $43 b$ & $\mathrm{ra} \cdot \mathrm{mu}$ \\
\hline $44 a$ & re·rang $\cdot k a$ & $44 \mathrm{~b}$ & ${ }^{1}$ rang $\cdot k a \quad{ }^{2}$ rang $\cdot k a$ \\
\hline $45 \mathrm{a}$ & re'ran'ting & $45 b$ & ran'ting \\
\hline $46 \mathrm{a}$ & re.ratta & $46 \mathrm{~b}$ & ${ }^{1} \mathrm{ra} \cdot \mathrm{ta}$ \\
\hline $47 \mathrm{a}$ & re·rong kong & $47 \mathrm{~b}$ & rong kong \\
\hline $48 \mathrm{a}$ & re-ru·gi & $48 \mathrm{~b}$ & $\mathrm{ru} \cdot \mathrm{gi}$ \\
\hline $49 \mathrm{a}$ & re·run·tuk & $49 \mathrm{~b}$ & run·tuk \\
\hline $50 \mathrm{a}$ & se'ra·but & $50 \mathrm{~b}$ & ${ }^{1}$ sa.but \\
\hline $51 \mathrm{a}$ & se·ram·puk & $51 \mathrm{~b}$ & sam.puk $v$, me-nyam·puk \\
\hline $52 \mathrm{a}$ & se'ran'dung, ter $\cdot$ se $\cdot$ ran $\cdot$ dung & $52 \mathrm{~b}$ & ${ }^{2}$ san'dung $v$, me'nyan'dung \\
\hline $53 a$ & se·ren·deng & $53 b$ & sen·deng \\
\hline $54 a$ & ${ }^{1}$ se're'ngam & $54 \mathrm{~b}$ & se'ngam $v$, me'nye'ngam \\
\hline $55 \mathrm{a}$ & se·ro'bok $v$, ber-se'ro'bok & $55 \mathrm{~b}$ & ${ }^{2}$ so $\cdot$ bok, ber·so $\cdot$ bok \\
\hline $56 \mathrm{a}$ & se·ro·dok & $56 \mathrm{~b}$ & ${ }^{2}$ so'dok $v$, me'nyo dok \\
\hline $57 \mathrm{a}$ & se·ron·dol $v$, me·nye'ron·dol & $57 \mathrm{~b}$ & son·dol \\
\hline $58 \mathrm{a}$ & se·ru·ak, me·nye·ru·ak & $58 \mathrm{~b}$ & ${ }^{3}$ su.ak $v$, me·nyu ak \\
\hline $59 \mathrm{a}$ & se.ru $\cdot d a$ & $59 \mathrm{~b}$ & su'da \\
\hline $60 \mathrm{a}$ & se·ru·duk $v$, me·nye·ru·duk & $60 \mathrm{~b}$ & ${ }^{2}$ su'duk \\
\hline $61 \mathrm{a}$ & se·ru·ling & $61 \mathrm{~b}$ & ${ }^{1}$ su $\cdot$ ling \\
\hline $62 \mathrm{a}$ & ${ }^{2}$ te-ri·tik $v$, ber-te-ri-tik & $62 \mathrm{~b}$ & ${ }^{1}$ ti-tik \\
\hline
\end{tabular}

Ket.: Angka kecil di depan kata-kata tersebut menyatakan bahwa kata-kata tersebut merupakan homonim (memiliki bentuk dan pengucapan yang sama, tetapi maknanya berbeda).

Berdasarkan bentuknya, pasangan kata berinfiks dan bentuk dasar pada tabel di atas dapat digolongkan ke dalam empat kelompok sebagai berikut.

\section{i) Bentuk berinfiksnya berupa morfem bebas}

Kata-kata yang masuk dalam kelompok ini merupakan kata berinfiks yang dapat berdiri sendiri sebagai kata dalam sebuah klausa atau kalimat dan tidak perlu dirangkaikan dengan morfem lain, baik morfem bebas (membentuk frase) maupun morfem terikat (membentuk polimorfemis dengan dua morfem terikat; infiks dan afiks lain). Kata-kata yang masuk dalam kelompok ini adalah berangus, berenggil, berewok, berumbung (1), ceranggah, gerenyot, gerigi, gerigis, gerinjal, gerohong, jerubung, jerumbai, kerakap, kerangkang, kerempung, keremunting, kerenyit, kerepak, kerepot, kerisut, kerocok, keropong, kerudung, perancit, perasukan, reramuan, rerangka, reranting, rerata, rerongkong, rerugi, reruntuk, serabut, serampuk, serendeng, serengam (1), serodok, dan seruling.

\section{ii) Bentuk dasarnya berupa morfem bebas}

Kata-kata yang masuk dalam kelompok ini merupakan bentuk dasar yang dapat berdiri sendiri sebagai kata dalam sebuah klausa atau kalimat dan tidak perlu dirangkaikan dengan morfem lain, baik morfem bebas (membentuk frase) maupun morfem terikat (membentuk polimorfemis). Kata-kata yang masuk dalam kelompok ini adalah bangus, benggil, bewok, bumbung, cacak (1), cacau, cancang (1), canggah (1), gagap (1), genyot, gigi, gigis (2), ginjal, gohong, jongkok, jubung, jumbai, kakap (4), kangkang, keceng, kempung (2), kemunting, kepot (1), kicau (1), kisut (1), kocok, kopong, kudung (2), kukut, ramu, rangka (1), rangka (2), ranting, rata (1), 
rongkong, rugi, runtuk, sabut (1), sendeng, sondol, suduk (2), suling (1), dan titik (1).

\section{iii) Bentuk dasar dan bentuk berinfiksnya berupa morfem bebas}

Kata-kata yang masuk dalam kelompok ini merupakan kata yang muncul dalam kedua kelompok di atas. Hal ini menunjukkan bahwa baik bentuk dasar maupun bentuk berinfiksnya merupakan morfem bebas yang dapat berdiri sendiri sebagai kata dalam konstruksi klausa atau kalimat. Kata-kata yang masuk dalam kelompok ini adalah berangus (bangus), berenggil (benggil), berewok (bewok), berumbung (1) (bumbung), ceranggah (' ${ }^{\text {canggah), }}$ gerenyot (genyot), gerigi (gigi), gerigis ( ${ }^{2}$ gigis), gerinjal (ginjal), gerohong (gohong), jerubung (jubung), jerumbai (jumbai), kerakap ( ${ }^{4}$ kakap), kerangkang (kangkang), kerempung ('kempung), keremunting (kemunting), kerepot ( ${ }^{1}$ kepot), kerisut ( ${ }^{1}$ kisut), kerocok (kocok), keropong (kopong), kerudung ( $\left.{ }^{2} k u d u n g\right)$, reremuan (ramu), rerangka ( ${ }^{1}$ rangka, ${ }^{2}$ rangka), reranting (ranting), rerata (rata), rerongkong (rongkong), rerugi (rugi), reruntuk (runtuk), serabut (sabut), serendeng (sendeng), dan seruling (suling).

\section{iv) Bentuk berinfiksnya berupa morfem terikat}

Kata-kata yang masuk dalam kelompok ini merupakan kata berinfiks yang tidak dapat berdiri sendiri sebagai kata dalam sebuah klausa atau kalimat dan harus dirangkaikan dengan morfem lain, baik morfem bebas (membentuk frase) maupun morfem terikat (membentuk polimorfemis dengan dua morfem terikat; infiks dan afiks lain). Kata-kata yang masuk dalam kelompok ini adalah cerabut, ceracak, ceracau, cerancang, ceratuk, geragap, gerapai, gerunyam, jeramah, jeremba, jerojol, jerongkok, kerenceng, kericau, kerukut, serandung, serobok, serondol, seruak, seruduk, dan teritik (2).

\section{v) Bentuk dasarnya berupa morfem terikat}

Kata-kata yang masuk dalam kelompok ini merupakan bentuk dasar yang tidak dapat berdiri sendiri sebagai kata dalam sebuah klausa atau kalimat dan harus dirangkaikan dengan morfem lain, baik morfem bebas (membentuk frase) maupun morfem terikat (membentuk polimorfemis). Kata-kata yang masuk dalam kelompok ini adalah cabut (cerabut), catuk (4) (ceratuk), gapai (gerapai), gunyam (gerunyam), jamah (jeramah), jemba (2) (jeremba), jojol (2) (jerojol), kenyit (kerenyit), kepak (3) (kerepak), pancit (perancit), pasuk (perasukan), sampuk (serampuk), sandung (2) (serandung), sengam ('serengam), sobok (2) (serobok), sodok (2) (serodok), dan suak (3) (seruak).

\section{vi) Bentuk dasar dan bentuk berinfiksnya berupa morfem terikat}

Kata-kata yang masuk dalam kelompok ini merupakan kata yang muncul dalam kelompok (iv) dan (v). Hal ini menunjukkan bahwa baik bentuk dasar maupun bentuk berinfiksnya merupakan morfem terikat yang tidak dapat berdiri sendiri sebagai kata dalam konstruksi klausa atau kalimat. Kata-kata yang masuk dalam kelompok ini adalah cerabut (cabut), ceratuk ( ${ }^{4}$ catuk), gerapai (gapai), gerunyam (gunyam), jeramah (jamah), jeremba $\left({ }^{2}\right.$ jemba $)$, jerojol $\left({ }^{2}\right.$ jojol $)$, serandung $\left({ }^{2}\right.$ sandung $)$, dan serobok $\left({ }^{2}\right.$ sobok $)$.

\section{vii) Ketumpangtindihan pembentukan kata}

Di dalam kata berinfiks -er- terdapat ketumpangtindihan pembentukan kata, yaitu infiksasi dan reduplikasi, yakni terdapat dalam kata reramuan, rerangka, reranting, rerata, rerongkong, rerugi, dan reruntuk. Dalam kata reramuan ditambah dengan proses pembentukan kata afiksasi. Ketumpangtindihan tersebut dapat dilihat dalam contoh, kata rerangka dapat dianalisis menggunakan infiksasi dan reduplikasi dwilingga. Pada proses infiksasi kata rangka langsung dilekati infiks -erpada suku pertama, sedangkan pada reduplikasi, prosesnya adalah rangka $\rightarrow$ rangka-rangka $\rightarrow$ rarangka $\rightarrow$ rerangka.

\subsection{Makna Kata Berinfiks -er-}

Berdasarkan kata berinfiks yang ditemukan dalam Kamus Besar Bahasa Indonesia Edisi Ketiga, penulis menemukan 14 makna yang terkandung di dalam infiks -er-, yaitu sebagai berikut. 
Tabel 2: Makna Kata Berinfiks -er-

\begin{tabular}{|c|c|}
\hline & (1) 'menyatakan makna sa \\
\hline 1 & $\begin{array}{l}\text { be·re·wok /beréwok/ } n \text { bulu atau rambut yg tumbuh pd } \\
\text { dagu dan pipi belakang; bewok; cambang bauk }\end{array}$ \\
\hline 2 & $\begin{array}{l}\text { ce·ra·tuk, ber·ce·ra·tuk } v \text { duduk dng kepala menunduk } \\
\text { sedikit; tercatuk }\end{array}$ \\
\hline 3 & $\begin{array}{c}\text { ge·ra·pai } v \text {, meng·ge·ra·pai } v \text { meraba-raba hendak } \\
\text { memegang; mencapai-capai (ke atas, ke kiri, ke } \\
\text { kanan) hendak memegang dsb; menggapai }\end{array}$ \\
\hline 4 & ge·re·nyot /gerényot/ $a$ erot (mulutnya); seringai; kernyih \\
\hline 5 & ge·rin·jal $\operatorname{ark} n$ ginjal \\
\hline
\end{tabular}

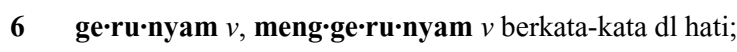
menggunyam

$7 \quad \mathbf{j e} \cdot \mathbf{r e m} \cdot \mathbf{b a}, \mathbf{m e n} \cdot \mathbf{j e} \cdot \mathbf{r e m} \cdot \mathbf{b a} v$ mengulurkan tangan (untuk mencapai sesuatu); menggapai

8 je·ru·bung $n$ Lay penutup muatan pd perahu (dibuat dr tikar, kajang, kain mota, dsb)

9 ke·ra·kap $M k n 1$ sirih yg daunnya lebar-lebar, lebih lebar dp sirih biasa dan tidak enak rasanya; 2 daun sirih yg tebal dan keras (lawan dr sirih carang)

10

ke·rang·kang $\longrightarrow$ kelangkang

ke·lang·kang $n \mathbf{1}$ bagian tubuh di antara kedua pangkal paha; 2 bagian belakang tubuh hewan di belakang pinggang

11 ke·rem·pung ark $n$ perut sebelah bawah

12 ke·re·mun·ting $\rightarrow$ kemunting

13 ke·ri·sut $a$ berkerut-kerut; lisut; kisut

14 ke·ro·pong $\rightarrow 2$ keropok

${ }^{2}$ ke·ro·pok $a \mathbf{1}$ tidak ada isinya; kosong; 2 berlubanglubang (berongga-rongga) krn lapuk dimakan rayap (tt kayu) atau dimakan panas (cuaca); 3 ki lemah; lembek

15 ke·ru·dung $n \mathbf{1}$ tudung (lampu dsb); 2 kain penutup kepala perempuan; cadar
${ }^{4}$ ca·tuk, ter·ca·tuk $v$ duduk dng kepala tertunduk sedikit

ga·pai $v$, ber·ga·pai·an $v$ mengulur-ulurkan tangan hendak mencapai atau memegang

ge·nyot /gényot/ $a$ tidak sejalan (tt garis dsb); erot

gin·jal $n$ (sepasang) organ tubuh (berbentuk spt biji kacang merah, terletak di dekat tulang belakang), berfungsi mengeluarkan atau memisahkan produk buangan metabolisme dr darah; buah pinggang

gu·nyam $v$, meng·gu'nyam $v$ berkata-kata $\mathrm{dl}$ hati

${ }^{2}$ jem·ba, men·jem·ba $v$ mengulurkan tangan (hendak memegang sesuatu)

ju·bung $\rightarrow$ jerubung

${ }^{4}$ ka·kap $n$ daun sirih yg di bawah, kasar dan kaku; sirih kerakap

kang·kang $n \mathbf{1}$ celah di antara pangkal kedua paha; $\mathbf{2}$ jarak antara kaki kanan dan kaki kiri (tt kaki yg terbuka); 3 kelangkang; 4 bagian celana (seluar) di bawah pantat atau bagian depan celana (tempat kancing); pesak

${ }^{2}$ kem·pung $J w n \mathbf{1}$ bagian perut sebelah bawah; 2 gelembung

ke·mun·ting $n \mathbf{1}$ tumbuhan perdu, daunnya dapat dimakan, berasa sepat, biasa digunakan untuk ramuan obat sakit perut; Rhodomyrtus tomentosa; $\mathbf{2}$ daun kemunting

${ }^{1}$ ki-sut $a$ (ber)kedut krn kering, tua dsb; lisut; keriput

ko·pong a $\mathbf{1}$ kosong; tidak ada isinya; 2 tidak berisi daging buah (tt buah-buahan)

${ }^{2}$ ku·dung $n$ kain selubung (penutup) kepala; kerudung 
pe·ran·cit $\longrightarrow$ pancit

17

18

re·rong·kong lihat rongkong

19

se·ram·puk $v$ sampuk; bentur; antuk

21

se·ran·dung, ter·se'ran·dung $v$ terantuk (pd batu dsb); tersandung

22 se·ren·deng /seréndéng/ $a \mathbf{1}$ sendeng; miring sebelah; tinggi sebelah; sedeng; 2 ki kurang waras otaknya

23 'se·re·ngam $\rightarrow$ sengam

24

se·ro $\cdot b o k v$, ber $\cdot \mathbf{s e} \cdot \mathbf{r o} \cdot \mathbf{b o k} v$ bertemu (dr dua arah yg berlainan); berjumpa; bersobok

25

se·ron·dol $v$, me·nye·ron $\cdot d o l v$ menyundul

26 se·ru·ling $n$ alat musik tiup yg terbuat dr buluh, logam, dsb; suling pan'cit $v$, me·man $\cdot$ cit $v$ memancur (menyemprot) sedikit demi sedikit

pa·suk, ber·pa'suk-pa·suk $v$ berkelompok-kelompok; berkawan-kawan

rong·kong $n \mathbf{1}$ tulang-tulang dl tubuh; rangka; 2 tenggorok binatang; rangkungan

run·tuk $\rightarrow$ reruntuk

sam·puk $v$, me·nyam·puk $v 1$ melanggar; menabrak; menumbuk; membentur; 2 menyambut (pukulan dsb); menangkis; $\mathbf{3}$ menepis tangan (yg sedang memegang senjata dsb); 4 memotong (pembicaraan orang); menyelang; 5 mencampuri (urusan orang dsb)

${ }^{2}$ san·dung $v$, me·nyan·dung $v$ menyentuh sesuatu dng tidak sengaja (tt kaki)

sen·deng /séndéng/ a 1 tinggi sebelah senget; condong; tidak rata (bahu); miring letaknya (kopiah di kepala); 2 juling (mata); 3 kurang ingatan; agak gila

se·ngam $v$, me·nye·ngam $v$ kas memakan sampai habis; memakan dng rakus

${ }^{2}$ so $\cdot$ bok, ber·so $\cdot$ bok $v$ bertemu (dng); berjumpa (dng); bersua (dng); tersobok

son·dol $\rightarrow$ sundul

sun·dul $v$, me·nyun'dul $v \mathbf{1}$ menundukkan kepala untuk menumbuk benda yg ada di atasnya: kerbau itu -nya sehingga ia terpental; 2 menangkis bola dng kepala

${ }^{1}$ su·ling $n 1$ seruling; bangsi; 2 peluit (kapal, kereta api, dsb)

\section{(2) 'menyatakan alat'}

1 be·ra・ngus $n$ selongsong penutup yg terbuat dr kulit ba·ngus $J k n$ moncong anjing atau babi atau rotan yg dianyam untuk menutup moncong anjing (supaya jangan menggigit) atau moncong anak sapi (supaya jangan menyusu)

2 be·rum·bung $n$ pembuluh (tempat mengalirkan

bum·bung $n 1$ tabung bambu; perian; 2 ark pembuluh; buluh-buluh atau menyalurkan air, asap, dsb); pipa; corong

\section{(3) 'menyatakan (sesuatu yang) mengambil sifat'}

1 ce·rang·gah $n$ cabang-cabang (tt tanduk rusa); rangga 'cang·gah $n 1$ galah (tongkat dsb) yg ujungnya bercabang (untuk senjata, menggancu, dsb); 2 dahan yg bercabang dua 
2 re·ra·ta $n 1$ nilai, angka, dsb yg paling umum; nilai dsb rata-rata; 2 Stat statistik yg menunjukkan nilai yg paling umum atau pertengahan di antara nilai-nilai variabel acak yg telah diukur
${ }^{1}$ ra·ta $a 1$ mempunyai permukaan yg sama tinggi dan/atau sama rendah; papar; $\mathbf{2}$ meliputi semua bagian; $\mathbf{3}$ tersebar ke segenap penjuru; terdapat (ditemukan) di seluruh tempat; 4 sama-sama memperoleh jumlah yg sama

\section{(4) 'menyatakan ketidaksengajaan'}

$1 \quad$ ce·ra·but $v$, ter·ce·ra $\cdot$ but $v 1$ merosot; 2 terlepas

ca'but $v$, men·ca·but $v 1$ menarik supaya lepas (keluar) dr tempat tertanamnya (tumbuhnya); $\mathbf{2}$ menarik keluar dr sarungnya (keris, pedang, pistol, dsb); menghunus; 3 mengambil salah satu dr kelompok yg besar (spt undian); 4 menarik kembali apa yg sudah dikatakan (dikeluarkan, diberikan, dsb); 5 menyatakan tidak berlaku; membatalkan (peraturan, izin, dsb)

\section{(5) 'menyatakan penyangatan atau penguatan makna'}

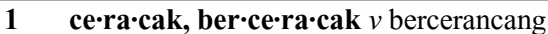

ber·ce·ran·cang·an $v$ mencuar-cuar tajam (tinggi-

tinggi)

2

ce·ran·cang, ber·ce·ran·cang·an $v$ mencuar-cuar tajam (tinggi-tinggi)

3 ge·ro·hong $n$ gerohok

ge·ro'hok $n$ lubang besar (pd pohon)

4 je·ra'mah, ber $\cdot \mathbf{j e} \cdot \mathbf{r a} \cdot \mathbf{m a h} v$ berpegang-pegangan sambil renggut-merenggut

$5 \quad$ je·rong·kok $v$, men·je·rong·kok $v$ berjongkok dng lutut hampir menyentuh dagu
1 can·cang $n$ pancang; ter-can·cang $v$ berdiri tegak lurus; (tampak) mencuar tegak lurus; terpancang

go·hong $n \mathbf{1}$ liang; lubang; 2 gua

ja·mah $v$, men·ja·mah $1 v$ menyentuh dng jari; meraba; memegang; 2 ki meniduri; menodai

jong·kok $v \mathbf{1}$ menempatkan badan dng cara melipat kedua lutut, bertumpu pd telapak kaki, dng pantat tidak menjejak tanah; bercangkung; berjongkok; 2 ki rendah (tt inteligensi)

\section{(6) 'menyatakan (melakukan) perbuatan'}

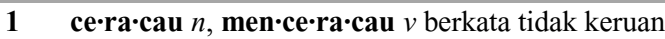
spt orang tidak sadar (tidur, gila, dsb); mengigau, mengaco-belo

2 e·ra·gap, meng·ge·ra·gap $v$ tidak tahu apa yg harus dikatakan; gugup; terkejut

3 ca·cau $a$ banyak bicara, cerewet (tt orang); banyak, senang, atau sering berkicau (tt burung dsb)

ga.gap $n 1$ gangguan bicara (kesalahan dl ucapan dng mengulangulang bunyi, suku kata, atau kata); 2 Psi kelainan wicara berupa pengulangan konsonan dan suku kata secara spasmodis, disebabkan oleh gangguan psikofisiologis dan lebih banyak terjadi pd pria

${ }^{3}$ su·ak $v$, me•nyu·ak $v$ menyibakkan (rambut, air, dsb)

menguakkan (menyibakkan) sesuatu yg menghalanginya ke kiri dan kanan (dl kerumunan orang, semak-semak, tempat yg sempit, dsb): ia masuk - orang banyak; 2 menjorok masuk: dagu-nya bercelah, dan matanya yg biru - ke dalam; 3 ki menembus (tt tatapan mata) 
$4 \quad$ se·ru·duk $v$, me·nye·ru·duk $v 1$ menyeluduk; menyuruk; menyusup: ia - ke dl belukar; 2 membungkuk dan menyundul; menanduk: kerbau itu - orang kemarin; 3 melanggar; menabrak (dng gerakan maju)

5

se·ro·dok $\rightarrow$ seruduk

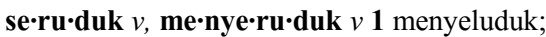
menyuruk; menyusup: ia - ke dl belukar; 2 membungkuk dan menyundul; menanduk: kerbau itu - orang kemarin; 3 melanggar; menabrak (dng gerakan maju)
${ }^{2}$ su·duk $\rightarrow$ 2sodok

${ }^{2}$ so·dok $v$, me·nyo·dok $v 1$ menolak; mendorong; menyorong (becak dsb); 2 menumbuk (menekan) dng tangan terkepal atau dng benda bulat panjang (di perut dsb); menggocok; 3 kas menyetubuhi; $\mathbf{4}$ cak mendahului kendaraan lain dng melarikan kendaraan sendiri cepat-cepat (dl suatu antrean kendaraan dsb); menyalib dng mengebut

${ }^{2}$ so·dok $v$, me·nyo·dok $v 1$ menolak; mendorong; menyorong (becak dsb); 2 menumbuk (menekan) dng tangan terkepal atau dng benda bulat panjang (di perut dsb); menggocok; 3 kas menyetubuhi; 4 cak mendahului kendaraan lain dng melarikan kendaraan sendiri cepat-cepat (dl suatu antrean kendaraan dsb); menyalib dng mengebut
$2 \quad$ je·rum·bai $n$ jerabai; jumbai-jumbai

3

re·ra·mu·an lihat ramu

4 re·rang.ka lihat rangka

5 re·ran·ting lihat ranting

$6 \quad$ se·ra·but $n \mathbf{1}$ serat-serat spt pd sabut; 2 barang yg rupanya spt bulu atau serat; 3 sabut halus; $\mathbf{4}$ struktur jaringan yg berbentuk panjang spt benang

\section{(7) 'menyatakan banyak atau kumpulan'}

1 ge·ri-gi $n$ gigi-gigi tajam pd tepi (gergaji, piringan sepeda)

gi-gi $n \mathbf{1}$ tulang keras dan kecil-kecil berwarna putih yg tumbuh tersusun berakar di dl gusi dan kegunaannya untuk mengunyah atau menggigit; $\mathbf{2}$ sesuatu yg bentuknya spt gigi: -- sisir; -gergaji; 3 ki kekuasaan

jum·bai $n$ rumbai

ra·mu $v$ kumpul; urun; menjadikan satu (pendapat, akar-akaran, kayu-kayuan)

${ }^{1}$ rang·ka $n$ tulang-tulangan (tubuh, barang, rumah, dsb); kerangka

ran·ting $n \mathbf{1}$ bagian cabang yg kecil-kecil; cabang dr cabang: penghuni gubuk itu mengumpulkan -- kecil untuk kayu api; 2 anak cabang dr perkumpulan dsb: 3 cabang sekunder pd pembuluh darah atau pembuluh saraf

'sa·but $n$ kulit yg berserat buah kelapa, pinang, dsb

${ }^{1}$ ti.tik $n$ noktah (pd huruf, tanda, tanda baca, dsb)

\section{(8) 'menyatakan membuat makna lebih generik'}

$1 \quad$ je·ro·jol, men·je·ro·jol $v$ menyembul ke luar

${ }^{2}$ jo·jol, men·jo·jol $v$ menganjur ke luar, menonjol ke luar; tersembul (tt mata)

$2 \quad$ ke·ru·kut $v$, me·nge·ru'kut $v$ berkerut-kerut (tt

ku·kut $\rightarrow$ kokot daun yg kena penyakit); kokot (tt jari); mengerut (tt tangan dan kaki);

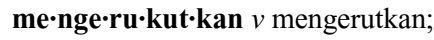
menggulungkan

${ }^{1}$ ko $\cdot k o t ~ n 1$ besi (kawat) yg dibengkokkan untuk memaut; gembok; 2 bengkok dan melekat (tt jari tangan, kaki,dsb); kerukut 


\begin{tabular}{|c|c|c|}
\hline \multicolumn{3}{|c|}{ (10) 'menyatakan kontinuitas' } \\
\hline 1 & $\begin{array}{l}\text { ke·ri·cau, ber } \cdot \text { ke·ri·cau } v \text { berkicau terus-menerus } \\
\quad(\mathrm{tt} \text { burung murai } \mathrm{dsb})\end{array}$ & $\begin{array}{l}{ }^{1} \text { ki } \mathbf{c} \text { cau } n \mathbf{1} \text { bunyi burung (terutama burung murai); } \mathbf{2} k i \text { celoteh; } \\
\quad \text { perkataan yg sebarang saja }\end{array}$ \\
\hline \multicolumn{3}{|c|}{ (11) 'menyatakan intensitas (keseringan) atau berkali-kali' } \\
\hline 1 & $\begin{array}{l}\text { ke·re·ceng } / \text { kerécéng/ } v \text {, me·nge·re·ceng·kan } \\
\text { (mata) } v \text { mengejap-ngejapkan (mata) }\end{array}$ & ke·ceng /kécéng/ $a$ dl keadaan tertutup sebelah (tt mata) \\
\hline
\end{tabular}

\begin{tabular}{|c|c|c|}
\hline \multicolumn{3}{|c|}{ (12) 'menyatakan hasil' } \\
\hline 1 & ke·re·nyit $\rightarrow$ kernyit & $\begin{array}{l}\text { ke'nyit, me·nge } \cdot \text { nyit } v \text { mengerutkan alis (mengejapkan mata) untuk } \\
\text { memberi isyarat; mengerling }\end{array}$ \\
\hline & ker·nyit $n$ kerut alis (dahi) & \\
\hline 2 & ke·re·pot $/$ kerépot $/ \longrightarrow$ keriput & ${ }^{1}$ ke·pot /képot/ $a$ erot; gumal; berkerut-kerut \\
\hline
\end{tabular}

\begin{tabular}{|c|c|c|}
\hline \multicolumn{3}{|c|}{ (13) 'menyatakan bunyi atau tiruan bunyi' } \\
\hline 1 & ke·re·pak $\rightarrow$ kerpak & $\begin{array}{l}{ }^{3} \text { ke·pak } / \mathrm{képak} / v \text {, ter·ke·pak } a \text { patah atau bengkok (tt dahan kayu, } \\
\text { lengan, dsb) }\end{array}$ \\
\hline & ker·pak $n$ bunyi spt bunyi cabang kayu patah & \\
\hline 2 & $\begin{array}{l}\text { ke·ro·cok } n \mathbf{1} \text { bunyi "cok, cok", spt bunyi air dl } \\
\text { botol yg dikocok; } \mathbf{2} \text { semacam orok-orok (nama } \\
\text { bunyi-bunyian) }\end{array}$ & ko·cok $v$ guncang (tt obat dl botol dsb) \\
\hline
\end{tabular}

\section{(14) 'menyatakan sifat'}

1 be·reng.gil ark $a$ menonjol (tersembul) ke luar (spt beng·gil $a$ benjol; bincul; bengkil mata kepiting, biji jambu monyet)

2 ge·ri-gis $a$ bergigi atau bertakik-takik tajam (spt $\quad{ }^{2}$ gi-gis $a$ cuil-cuil pd pinggirnya (tt gigi anak kecil yg kupak) mata pisau yg rusak, kikir)

Selain kata-kata di atas, penulis juga menemukan kata yang diduga merupakan kata berinfiks -er-. Hal ini didasarkan pada kemiripan makna di antara dugaan bentuk berinfiks dan dugaan bentuk dasarnya. Kata di bawah ini dapat dijadikan penelitian lebih lanjut mengenai infiks dalam bahasa Indonesia. Untuk menetapkan bentuk di bawah ini merupakan gejala infiks, dibutuhkan penelitian yang bersifat diakronis. Kata tersebut adalah sebagai berikut.

Tabel 3: Dugaan Bentuk Kata Berinfiks -er-

\begin{tabular}{|c|c|c|c|}
\hline No. & Dugaan Bentuk Berinfiks & Dugaan Bentuk Dasar & Keterangan \\
\hline 1 & $\begin{array}{l}\text { be·ri·sik } J k \text { a } 1 \text { ribut (ramai, hingar-bingar) } \\
\text { suaranya: saya tidak dapat tidur krn } \\
\text { anak-anak -- di luar; } \mathbf{2} \text { berasa } \\
\text { mendengung pd telinga }\end{array}$ & $\begin{array}{l}\text { bi·sik } n \text { suara desis perlahan-lahan: sering } \\
\text { kali terngiang dl telingaku -- rayu } \\
\quad \text { kekasihku; }\end{array}$ & $\begin{array}{l}\text { Keduanya tidak memiliki } \\
\text { kesamaan atau kemiripan } \\
\text { makna. Akan tetapi, yang } \\
\text { menonjol di antara keduanya } \\
\text { adalah pertentangan makna } \\
\text { (antonim). }\end{array}$ \\
\hline 2 & $\begin{array}{l}\text { be·rum·bun } M k \text {, ter·be·rum } \cdot \text { bun } a \mathrm{dl} \\
\text { keadaan menjulang dan besar; tesergam }\end{array}$ & ${ }^{1}$ bum $\cdot$ bun ark $a$ rimbun; rindang & $\begin{array}{l}\text { Keduanya memiliki } \\
\text { kemiripan makna, yaitu }\end{array}$ \\
\hline
\end{tabular}


Prima Hariyanto: Kata Berinfiks -er- dalam Bahasa Indonesia

\begin{tabular}{|c|c|c|c|}
\hline & & & 'besar' dan 'rindang.' \\
\hline 3 & $\begin{array}{l}\text { ge·re·sek /gerésék/, meng·ge·re·sek } v \\
\text { berbunyi kersik-kersik }\end{array}$ & $\begin{array}{c}\text { ge·sek /gésék/ } v \text {, ber·ge·sek } v \text { bergosokan; } \\
\text { bergesel; bergeseran: bunyinya sbg } \\
\text { kayu } \sim \text {; kalau dua benda selalu } \sim, \\
\text { lama-kelamaan aus }\end{array}$ & $\begin{array}{l}\text { Keduanya memiliki } \\
\text { kemiripan konsep makna, } \\
\text { yaitu 'bergeseran' dan } \\
\text { 'berbunyi kersik-kersik' } \\
\text { seperti bunyi benda } \\
\text { bergesekan. }\end{array}$ \\
\hline 4 & $\begin{array}{l}\text { ke·ra·bat } n \mathbf{1} \text { yg dekat (pertalian keluarga); } \\
\text { sedarah sedaging: masih -- dng engkau; } \\
\mathbf{2} \text { keluarga; sanak saudara: kaum --; } \mathbf{3} \\
\text { keturunan dr induk yg sama yg } \\
\text { dihasilkan dr gamet yg berbeda; }\end{array}$ & $\begin{array}{l}\text { ka'bat } M k v, \text { me·nga } \cdot \text { bat } v \text { mengikat; } \\
\text { mengebat: } \sim \text { kayu bakar }\end{array}$ & $\begin{array}{l}\text { Keduanya memiliki } \\
\text { kemiripan konsep makna, } \\
\text { yaitu 'yang dekat (pertalian } \\
\text { keluarga)' dan 'mengikat.' }\end{array}$ \\
\hline 5 & $\begin{array}{l}\text { ke·ra·wat } n \text { tali dr kulit rotan (untuk } \\
\text { mengikat beliung); tali rotan }\end{array}$ & $\begin{array}{l}\text { ka'wat } n \mathbf{1} \text { tali yg dibuat dr logam; } 2 \\
\text { telegram; }\end{array}$ & $\begin{array}{l}\text { Keduanya memiliki } \\
\text { kesamaan komponen makna, } \\
\text { yaitu 'tali.' }\end{array}$ \\
\hline 6 & $\begin{array}{l}\text { ke·ren·cang } n \text { tiruan bunyi rantai } \\
\text { bersentuhan }\end{array}$ & $\begin{array}{l}{ }^{2} \text { ken·cang } n \text {, ken·cang-ken·cung } n \text { tiruan } \\
\text { bunyi "cang, cing, cung" }\end{array}$ & $\begin{array}{l}\text { Keduanya memiliki } \\
\text { kesamaan komponen makna, } \\
\text { yaitu 'tiruan bunyi.' }\end{array}$ \\
\hline 7 & $\begin{array}{l}\text { ke·ren·cung } n \text { tiruan bunyi, hampir sama } \\
\text { dng bunyi kerencang }\end{array}$ & ken·cung $n$ tiruan bunyi "cung, cung" & $\begin{array}{l}\text { Keduanya memiliki } \\
\text { kesamaan komponen makna, } \\
\text { yaitu 'tiruan bunyi.' }\end{array}$ \\
\hline 8 & $\begin{array}{c}{ }^{2} \text { ke·ren·dang } n \text { wadah penyimpanan benih } \\
\text { ikan sebelum diangkut ke tempat lain }\end{array}$ & $\begin{array}{l}{ }^{2} \text { ken·dang } n \text { kemasan kertas berisi antara } \\
\quad 480-500 \text { helai; rim; } \\
\text { se'ken·dang } n \mathbf{1} \text { satu rim; } 2 \mathrm{Jw} \\
\text { banyak sekali: jika itu yg } \\
\text { kaumaksudkan, saya punya } \sim\end{array}$ & $\begin{array}{l}\text { Keduanya memiliki } \\
\text { kesamaan komponen makna, } \\
\text { yaitu 'wadah atau kemasan.' }\end{array}$ \\
\hline 9 & $\begin{array}{l}\text { ke·ri·ut } n \text { bunyi "kiut-kiut", spt bunyi } \\
\text { gesekan pohon bambu ditiup angin; } \\
\text { ber·ke·ri·ut } v \text { berbunyi "kiut-kiut"; } \\
\text { ber·ke·ri·ut·an } v \text { berkeriut berkali-kali }\end{array}$ & $\begin{array}{l}\text { ki·ut } \rightarrow \text { kicut } \\
\text { ki·cut } v \text { bunyi "cut, cut", spt as roda yg } \\
\quad \text { kurang minyak; }\end{array}$ & $\begin{array}{l}\text { Keduanya memiliki } \\
\text { kesamaan komponen makna, } \\
\text { yaitu 'bunyi.' }\end{array}$ \\
\hline 10 & 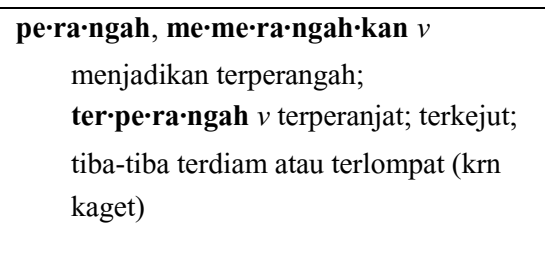 & pa·ngah, ter·pa'ngah $v$ ternganga & $\begin{array}{l}\text { Keduanya memiliki } \\
\text { kemiripan konsep makna, } \\
\text { yaitu 'terperangah' dan } \\
\text { 'ternganga' yang biasanya } \\
\text { disebabkan oleh terkejut atau } \\
\text { terperangah. }\end{array}$ \\
\hline 11 & $\begin{array}{l}\text { se·ru·da } n \text { serangkak (duri-duri, ranting- } \\
\text { ranting yg dipasang pd pohon agar } \\
\text { pohon tidak dipanjat orang) }\end{array}$ & $\begin{array}{c}\text { su·da } k l n \text { bambu atau bilah bambu yg } \\
\text { dibuat runcing dan dipasang di } \\
\text { keliling kubu dsb sbg ranjau }\end{array}$ & $\begin{array}{l}\text { Keduanya memiliki } \\
\text { kesamaan konsep makna, } \\
\text { yaitu 'benda yang digunakan } \\
\text { untuk menghalau orang } \\
\text { (sesuatu).' }\end{array}$ \\
\hline
\end{tabular}

\subsection{Metode Pendefinisian Lema Kata Berinfiks} yang Bermakna 'Sama dengan Bentuk

Dasarnya'

Sebagaimana dijelaskan dalam bagian sebelumnya, sebagian besar kata berinfiks -ermemiliki makna yang sama dengan bentuk dasarnya. Sebanyak 26 kata berinfiks maknanya sama dengan bentuk dasarnya. Akan tetapi, 26 kata tersebut masih dapat dikelompokkan lagi berdasarkan nuansa maknanya lebih lanjut. Adapun kata-kata tersebut dapat digolongkan ke dalam lima kelompok. Kelima kelompok tersebut adalah sebagai berikut.

\section{i) Rujuk silang ke bentuk dasar atau rujuk silang ke bentuk berinfiks}

Kata-kata ini cukup mudah diidentifikasi sebagai kata berinfiks mengingat perbedaan makna pada bentuk dasar dengan bentuk berinfiksnya tidak ada. 
Perbedaannya hanya terletak pada ragam penggunaannya. Kata yang dirujuk silang merupakan kata yang tidak disarankan penggunaannya karena merupakan kata yang tidak baku. Sebagai contoh, dalam lema keremunting $\rightarrow$ kemunting, kata keremunting tidak disarankan penggunaannya (tidak baku) sehingga merujuk silang ke kata kemunting yang disarankan penggunaannya. Kata-kata yang masuk dalam kelompok ini adalah sebagai berikut.

Tabel 4: Lema yang Berujuk Silang

\begin{tabular}{|l|l|l|}
\hline \multicolumn{1}{|c|}{ Kata Berinfiks } & \multicolumn{1}{|c|}{ Bentuk Dasar } & Yang Disarankan Digunakan (Baku) \\
\hline je·ru·bung & ju·bung $\rightarrow$ jerubung & jerubung (bentuk berinfiks) \\
\hline ke·re·mun·ting $\rightarrow$ kemunting & ke·mun·ting & kemunting (bentuk dasar) \\
\hline pe·ran·cit $\rightarrow$ pancit & pan·cit & pancit (bentuk dasar) \\
\hline re·run·tuk & run·tuk $\rightarrow$ reruntuk & reruntuk (bentuk berinfiks) \\
\hline 'se·re·ngam $\rightarrow$ sengam & se·ngam & sengam (bentuk dasar) \\
\hline
\end{tabular}

ii) Pendefinisian lema kata berinfiks mengandung bentuk dasarnya

Kata-kata pada kelompok ini juga masih cukup mudah diidentifikasi karena persamaan antara kata berinfiks dan bentuk dasarnya masih tersurat, yaitu dalam definisi bentuk berinfiksnya terkandung bentuk dasarnya. Sebagai contoh lema gerunyam diberi definisi (makna) 'berkata dalam hati; menggunyam.' Kata menggunyam merupakan bentukan dari kata gunyam. Dengan demikian, dapat disimpulkan bahwa gerunyam dan gunyam memiliki makna yang sama. Bahkan, beberapa kata seperti perasukan dan serampuk definisinya adalah bentuk dasarnya itu sendiri. Kata-kata yang masuk dalam kelompok ini adalah berewok (bewok), ceratuk (catuk), gerapai (gapai), gerunyam (gunyam), gerinjal (ginjal), kerisut (kisut), perasukan (pasukan), serampuk (sampuk), serandung (sandung), serendeng (sendeng), serobok (sobok), dan seruling (suling).

\section{iii) Pendefinisian lema bentuk dasar mengandung kata berinfiksnya}

Kata-kata pada kelompok ini merupakan kebalikan dari kata-kata pada kelompok sebelumnya. Jika pada kelompok sebelumnya terdapat bentuk dasar dalam definisi lema kata berinfiksnya, dalam kelompok ini, terdapat kata berinfiks dalam definisi lema bentuk dasarnya. Sebagai contoh, dalam definisi lema kudung terdapat definisi 'kain selubung (penutup) kepala; kerudung.' Dengan demikian, dapat disimpulkan bahwa kudung dan kerudung memiliki makna yang sama. Kata-kata yang masuk dalam kelompok ini adalah kerakap (kakap), kerudung (kudung), dan seruling (suling). Kata suling dan seruling masuk dalam ketegori ini dan kategori sebelumnya. Dengan demikian, kata suling dan seruling dianggap hanya saling menggantikan saja.

\section{iv) Pendefinisian lema bentuk berinfiks merujuk \\ ke lema bentuk dasarnya}

Kelompok ini berbeda dengan kelompok (i). Pada kelompok (i) lema yang dirujuk silang (dengan menggunakan tanda $\rightarrow$ ) tidak disarankan penggunaannya, sedangkan dalam kelompok ini, lema yang dirujuk silang (dengan menggunakan kata lihat) masih disarankan penggunaannya. Pada umumnya, lema yang dirujuk silang dengan menggunakan kata lihat menjadi sublema pada lema lainnya. Sebagai contoh, kata temali yang dirujuk ke lema tali (1) dapat dilihat maknanya pada lema tali (1) dan menjadi sublema pada lema tali (1).

Di dalam data, ditemukan lema rerongkong yang merujuk ke lema rongkong, yaitu dengan menggunakan kata lihat. Di dalam petunjuk pemakaian Kamus Besar Bahasa Indonesia Edisi Ketiga, disebutkan bahwa lema atau sublema yang merupakan gabungan kata yang deskripsi maknanya terdapat pada lema lain digunakan kata lihat (Tim Penyusun, 2007: xxx). Dengan demikian, dapat dikatakan bahwa arti kata rerongkong dapat dilihat di lema rongkong. Akan tetapi, jika kita melihat lema rongkong, tidak ditemukan sublema rerongkong. 
v) Persamaan konsep makna keterangan lema bentuk dasar dan keterangan lema kata berinfiksnya

Kata-kata pada kelompok kelima ini merupakan kata-kata yang memiliki pasangan dengan konsep makna yang sama atau merujuk pada hal atau sesuatu yang sama. Kata-kata ini pada dasarnya juga mudah untuk diidentifikasi sebagai kata berinfiks mengingat baik bentuk berinfiks maupun bentuk dasarnya memiliki makna yang sama secara eksplisit. Sebagai contoh, pasangan jeremba dan jemba (2) dimasukkan sebagai pasangan kata berinfiks karena keduanya memiliki kesamaan makna secara eksplisit, yaitu 'mengulurkan tangan (untuk mencapai sesuatu); menggapai' dan 'mengulurkan tangan (hendak memegang sesuatu).'

Kata-kata yang masuk dalam kelompok ini adalah gerenyot (genyot), jeremba (jemba), kerangkang (kangkang), kerempung ( ${ }^{2}$ kempung), keropong (kopong), dan serondol (sondol). Dari keenam kata tersebut, terdapat dua kata berinfiks yang tidak disarankan penggunaannya, yaitu kerangkang dan keropong. Kata kerangkang merujuk pada kata kerangkang, sedangkan keropong merujuk pada kata keropok (2).

\section{PENUTUP}

\subsection{Simpulan}

Berdasarkan pemaparan sebelumnya, penulis menyimpulkan beberapa hal sebagai berikut. Infiks merupakan bentuk terikat yang berupa afiks yang dilekatkan di "tengah" bentuk kata. Berdasarkan penelitian ini, di dalam Kamus Besar Bahasa Indonesia Edisi Ketiga ditemukan jenis infiks -er- dan terdapat sebanyak 62 kata berinfiks -er-. Berdasarkan penelitian, ditemukan sebanyak empat belas makna infiks -er-. Hal ini menunjukkan adanya perkembangan makna infiks dari yang awalnya hanya terdiri dari empat makna-menurut Kridalaksana (1992) — menjadi empat belas makna.

\subsection{Saran}

Penelitian mengenai infiks dalam bahasa Indonesia ternyata memiliki cakupan yang cukup luas. Hal ini terlihat dari banyaknya permasalahan yang berkaitan dengan infiks dalam bahasa Indonesia. Oleh karena itu, penelitian ini merupakan penelitian yang belum mengkaji keseluruhan permasalahan dalam infiks sehingga perlu diadakan penelitian lebih lanjut mengenai infiks dalam bahasa Indonesia.

Penelitian lanjutan dapat diarahkan ke penelitian etimologi bentuk berinfiks yang terdapat dalam naskah maupun kamus-kamus kuno yang merekam bahasa-bahasa pada zaman dahulu yang merupakan cikal bakal bahasa Indonesia. Di samping itu, terdapat pula kemungkinan adanya pengaruh infiks dari bahasa-bahasa lain, seperti bahasa Jawa atau bahasa Melayu. Selain itu, penelitian tentang ketumpangtindihan proses morfologis infiksasi dengan proses morfologis lain, seperti prefiksasi dan reduplikasi juga merupakan penelitian yang menarik untuk dilanjutkan. Seperti kita ketahui, selain infiks -erjuga masih terdapat jenis infiks lain yang belum dibahas. Oleh karena itu, bentuk infiks lain juga perlu diteliti dan memiliki banyak manfaat bagi perkembangan linguistik bahasa Indonesia.

\section{DAFTAR PUSTAKA}

Alwi, Hasan, dkk. 1998. Tata Bahasa Baku Bahasa Indonesia, Edisi Ketiga. Jakarta: Balai Pustaka.

Balai Pustaka. 2004. Pedoman Umum Ejaan yang Disempurnakan. Jakarta: Balai Pustaka.

Balai Pustaka. 2005. Kamus Besar Bahasa Indonesia, Edisi Ketiga. Jakarta: Balai Pustaka.

Crawford, John. 1852. A Grammar and Dictionary of the Malay Language. London: Smith, Elder, and Co.

Dumaria. 2009. "Manfaat Kamus Besar Bahasa Indonesia dalam Kehidupan Sehari-Hari,” disampaikan pada acara Bedah Kamus Besar Bahasa Indonesia Pusat Bahasa Edisi IV, Selasa, 24 Februari, di Bentara Budaya Jakarta.

Keraf, Gorys. 1984. Tata Bahasa Indonesia. Ende: Nusa Indah. 
Prima Hariyanto: Kata Berinfiks -er- dalam Bahasa Indonesia

Kridalaksana, Harimurti (ed.). 1991. Masa Lampau Bahasa Indonesia: Sebuah Bunga Rampai. Yogyakarta: Kanisius.

Kridalaksana, Harimurti, dkk. 2007. "Dasar-Dasar Leksikografi dan Leksikologi: Bahan Pelatihan Penyusunan Kamus Dwibahasa (Indonesia/Melayu - asing, Indonesia/Melayu - daerah)”. Diktat. Depok: Pusat Leksikologi dan Leksikografi, Fakultas Ilmu Pengetahuan Budaya UI.

Kridalaksana, Harimurti. 1992. Pembentukan Kata dalam Bahasa Indonesia. Jakarta: Gramedia Pustaka Utama.

Kridalaksana, Harimurti. 1994. Kelas Kata dalam Bahasa Indonesia, Edisi Kedua. Jakarta: Gramedia Pustaka Utama.

Purwo, Bambang Kaswanti. 2009. "Bedah KBBI Edisi IV," disampaikan pada acara Bedah Kamus Besar Bahasa Indonesia Pusat Bahasa Edisi IV, Selasa, 24 Februari, di Bentara Budaya Jakarta.

Qodratillah, Meity Taqdir. 2009. “Kamus Besar Bahasa Indonesia Pusat Bahasa Edisi IV,” disampaikan pada acara Bedah Kamus Besar Bahasa Indonesia Pusat Bahasa Edisi IV, Selasa, 24 Februari, di Bentara Budaya Jakarta.

Smarapradhipa, Galih. 2009. "Membaca Kamus Besar Bahasa Indonesia Pusat Bahasa Edisi Keempat," disampaikan pada acara Bedah Kamus Besar Bahasa Indonesia Pusat Bahasa Edisi IV, Selasa, 24 Februari, di Bentara Budaya Jakarta.

Sudaryanto. 1988. Metode Linguistik. Yogyakarta: Gadjah Mada University Press.

Yusuf, A. Muri. 2007. Metodologi Penelitian. Padang: UNP Press. 